\title{
BÓL POOPERACYJNY W OPINII PACJENTA
}

\section{POSTOPERATIVE PAIN IN THE PATIENT'S OPINION}

\author{
Anna Gawęda ${ }^{1, a}$, Jolanta Kamińska, ${ }^{2, b}$, Genowefa Wawoczna ${ }^{3, c}$, Ewa Tobor ${ }^{4, d}$, \\ Dorota Ogonowska, e
}

${ }^{1}$ Wydział Opieki Zdrowotnej, Wyższa Szkoła Nauk Stosowanych w Rudzie Śląskiej

${ }^{2}$ Instytut Zdrowia, Państwowa Wyższa Szkoła Zawodowa, Nowy Sącz

${ }^{3}$ Absolwent, Wydział Opieki Zdrowotnej, Wyższa Szkoła Nauk Stosowanych w Rudzie Śląskiej

${ }^{4}$ Wydział Nauk Medycznych, Państwowa Medyczna Wyższa Szkoła Zawodowa, Opole

${ }^{a}$ https://orcid.org/0000-0003-3498-8902
${ }^{b}$ https://orcid.org/0000-0002-1297-3454
${ }^{\mathrm{c}}$ https://orcid.org/0000-0003-1548-6624
${ }^{d}$ https://orcid.org/0000-0001-5879-8754
${ }^{e}$ https://orcid.org/0000-0001-7637-324X

DOI: https://doi.org/10.20883/pielpol.2020.23

\section{STRESZCZENIE}

Wstęp. Choroba i związane z nią leczenie operacyjne oraz towarzyszący mu ból to zdarzenie szczególnie trudne. Uśmierzenie bólu to kwestia priorytetowa w leczeniu pooperacyjnym, wzmacnianiu wysiłków człowieka chorego do walki o swoje zdrowie.

Cel. Celem pracy było poznanie stopnia natężenia bólu oraz jego charakteru u pacjenta w sytuacji pooperacyjnej.

Materiał i metoda. Badanie przeprowadzono wśród 189 osób po zabiegach operacyjnych. W badaniu materiał badawczy pozyskano metodą sondażu diagnostycznego. Narzędziem badawczym był autorski kwestionariusz anonimowej ankiety badający poznanie poziomu i istoty bólu u pacjenta w sytuacji pooperacyjnej.

Wyniki. Pooperacyjny ból uwarunkowany był chorobą, czynnikami społecznymi, umiejscowieniem i rozległością, powikłaniami, czasem trwania dolegliwości oraz wcześniejszymi doświadczeniami. Operowani chorzy określili charakter swego bólu jako kłujący, ostry i nawracający. Objawami towarzyszącymi bólowi pooperacyjnemu według respondentów najczęściej były nudności i wymioty. Na ból pacjenci reagowali przyśpieszonym tętnem, reakcją nerwową, wzmożonym napięciem mięśni i podwyższonym ciśnieniem krwi oraz ograniczeniem aktywności ruchowej. W opinii badanych chorych ból zaburzał ich sen i obniżał nastrój. Wnioski. Zjawisko bólu pooperacyjnego w przeprowadzonym badaniu wskazuje na konieczność stałego monitorowania i wdrażania standardów minimalizacji bólu po zabiegach operacyjnych. Przeprowadzone badanie wskazuje na ciągłą potrzebę edukacji, informowania oraz wsparcia chorych w sytuacji pooperacyjnej.

SŁOWA KLUCZOWE: ból pooperacyjny, pacjent, pielęgniarka.

\begin{abstract}
Introduction. Disease and surgical treatment and the accompanying pain is a particularly difficult event. Relief of the pain is a priority issue in post-operative treatment, strengthening the efforts of a sick person to fight for the health.

Aim. The aim of the study was to find out the degree of pain intensity and its character in the patient.

Material and methods. The study was conducted among 189 people after surgical procedures. In the study, the research material was obtained by means of a diagnostic survey. The research tool was a questionnaire examining the cognition of level and essence of the pain in a patient in a post-operative situation.

Results. The postoperative pain was conditioned by the sickness, social factors, localization and extent, complications, duration of afflictions and previous experiences. Operated sick people defined the nature of their pain as piercing, sharp and recurrent. Symptoms associated with postoperative pain, according to respondents, were mostly nausea and vomiting. Patients responded to pain with the accelerated pulse, nervous reaction, increased tonus and high blood pressure, as well as limited physical activity. In the opinion of the examined sick people, the pain disturbed their sleep and lowered the mood.

Conclusions. The phenomenon of the post-operative pain in the conducted study indicates the need for constant monitoring and implementation of the pain minimization standards after surgical procedures. The conducted study indicates a continuous need for education, information and support for sick people in the postoperative situation.
\end{abstract}

KEYWORDS: postoperative pain, patient, nurse. 


\section{Wprowadzenie}

Według definicji Międzynarodowego Stowarzyszenia Badania Bólu (International Association Study of Pain, IASP) ból jest to nieprzyjemne doświadczenie czuciowe i emocjonalne, związane z rzeczywistym lub potencjalnym uszkodzeniem tkanek lub opisywane jako takie uszkodzenie [1]. Zjawisko to jest wielowymiarowe i subiektywne, które każdy człowiek doznaje i opisuje różnie [2, 3]. W organizmie człowieka ból spełnia funkcję: ostrzegawczą, ochronną i przystosowawczą.

Doznania bólowe można podzielić klinicznie na ból ostry i przewlekły. Pierwszy typ bólu związany jest z uszkodzeniem ciała lub chorobą. Pełni funkcję ostrzegawczą, a czas trwania i siła zależą od obszaru uszkodzenia lub natężenia choroby. Ostry typ bólu powstaje w przebiegu nagłego zdarzenia, urazu, zapalenia, w okresie okołooperacyjnym lub w migrenach [4]. Drugi typ bólu określany jest przewlekłym, jeśli dolegliwości utrzymują się dłużej niż trzy miesiące lub nawracają, albo utrzymują się po wygojeniu uszkodzenia tkanek [5]. Chorzy cierpiący przewlekle z powodu bólu, zależnie od czasu trwania i natężenia dolegliwości, skarżą się na pogorszenie jakości życia. Występują u nich zaburzenia fizjologiczne, psychologiczne i społeczne. U chorych często pojawia się przygnębienie, niepokój, drażliwość i zdenerwowanie. Występować mogą zaburzenia snu i łaknienia, zmniejsza się aktywność ruchowa i obniża próg bólowy. Przewlekły ból uznawany jest za odrębną jednostkę chorobową i wymaga wielokierunkowego leczenia [3].

Reakcja pacjenta na ból niesie ze sobą aspekt psychologiczny, reakcję hormonalną, mięśniową, wegetatywną. Niedostatecznie kontrolowany i źle leczony ból może prowadzić do pogorszenia zdrowia [6].

Wielu autorów wskazuje, iż ból pooperacyjny jest „samoograniczającym się zjawiskiem”, który swą najwyższą intensywność osiąga w pierwszych dwóch dobach po zabiegu i stopniowo zmniejsza się w kolejnych dniach. Operacje dokonywane w nadbrzuszu, okolicy krocza oraz torakotomie wskazywane są jako zabiegi niosące doznanie bólu o najwyższym i bardzo dokuczliwym stopniu. Miejsce zabiegu, zakres operacji, stopień urazu tkanek, wybór i kierunek cięcia to składowe wpływające również na poziom odczucia bólowego u pacjenta $[3,7,8]$. Nasilenie bólu pooperacyjnego powodują również objawy dodatkowe, jak np. wymioty, nudności czy kaszel. Zmiana pozycji ciała, podjęcie aktywności oraz wykonywane zabiegi: zmiany opatrunku, usunięcie drenu także wzmagają dolegliwości bólowe [7]. Leczenie bólu okołooperacyjnego jest istotnym elementem uzyskania sukcesu w leczeniu osoby chorej. Wczesne i skuteczne uśmierzenie bólu przyśpiesza gojenie się rany pooperacyjnej, zmniejsza ilość powikłań oraz zapobiega przekształceniu się w ból przetrwały, przewlekły. Działanie przeciwbólowe w okresie pooperacyjnym ułatwia podjęcie przez pacjenta aktywności i rehabilitacji, powoduje szybszy powrót do zdrowia, skraca pobyt w szpitalu, minimalizuje całkowite koszty leczenia oraz przyśpiesza powrót do aktywności zawodowej. Leczenie bólu po zabiegu operacyjnym ma przynieść ulgę w cierpieniu oraz zahamować „kaskadę procesów patofizjologicznych", doprowadzających do utrwalenia bólu i przedłużenia choroby i leczenia, a także do niechcianych powikłań [7].

\section{Cel pracy}

Głównym celem było poznanie stopnia natężenia bólu oraz jego charakteru u pacjenta w sytuacji pooperacyjnej. Cele szczegółowe: ocena natężenia bólu w okresie pooperacyjnym; ocena uwarunkowań bólu pooperacyjnego; poznanie oczekiwań badanych, co do rodzaju wsparcia ze strony personelu medycznego.

\section{Materiał}

Badanie zostało przeprowadzone na oddziałach: chirurgicznym, ginekologicznym, ortopedycznym, okulistycznym i otolaryngologicznym na terenie jednego ze szpitali miejskich Górnego Śląska. Badaniem zostali objęci pacjenci po zabiegach operacyjnych; przebadano 189 osób.

\section{Metoda badawcza}

W badaniu zastosowano metodę sondażu diagnostycznego, narzędziem badawczym był kwestionariusz anonimowej, autorskiej ankiety dla pacjentów po zabiegu operacyjnym, zawierający 40 pytań. Wśród pacjentów rozprowadzono 200 kwestionariuszy. Dalszej analizie poddano 189 prawidłowo wypełnionych kwestionariuszy ankiety.

\section{Analizy statystyczne}

Wszystkie obliczenia wykonano za pomocą pakietu statystycznego SPSS Statistics 21,0. Uzyskane dane poddano analizie opisowej, graficznej oraz statystycznej. Do analiz statystycznych wykorzystano test chi kwadrat, test t Studenta oraz test analizy wariancji ANOVA. Wartość prawdopodobieństwa $p<0,05$ uznano za statystycznie istotną.

\section{Wyniki}

\section{Charakterystyka grupy badanej}

Wśród badanych ponad połowę stanowiły kobiety ( $\mathrm{n}=$.., 58\%). Wiek badanych osób kształtował się między 23 a 83 lata. Najliczniejsza grupa badanych osób posiadała wykształcenie średnie ( $n=86 ; 45,5 \%)$. Ponad połowa ogółu ankietowanych pacjentów to osoby czyn- 
ne zawodowo. Niezatrudnieni stanowili prawie $28 \%$ ( $n=82$ ) ogółu badanych, z którego ponad 16\% ( $n=31)$ stanowili emeryci, a ponad $7 \%(n=14)$ renciści. Ponad połowa badanych ( $\mathrm{n}=110 ; 58,2 \%)$ to mieszkańcy dużych miast przekraczających liczbę 100000 mieszkańców.

\section{Natężenie bólu w okresie pooperacyjnym}

Na doznania bólowe po zabiegu operacyjnym ma wpływ rodzaj wykonanego zabiegu, rodzaj znieczulenia oraz tryb przyjęcia do szpitala. Największą grupą badanej populacji byli chorzy po zabiegu chirurgicznym ( $n=53$; $28 \%$ ). Prawie równolicznymi grupami ankietowanych byli pacjenci oddziału laryngologicznego ( $n=41 ; 21,7 \%)$ i ortopedycznego ( $n=42 ; 22 \%$ ). Mniej licznymi grupami były pacjentki po zabiegu ginekologicznym ( $n=27 ; 14,3 \%$ ) i pacjenci po operacji okulistycznej ( $n=26$; $14 \%$ ). Pacjenci po zabiegu operacyjnym określali natężenie bólu w skali od 0 do 10. Rozpiętość oceny bólu wynosiła od 2 do 8 , średnia natężenia bólu wynosiła 5,8. W znieczuleniu ogólnym operowanych było $36,5 \%$ badanych $(n=69)$, w znieczuleniu podpajęczynówkowym prawie jedna trzecia badanych ( $n=61 ; 32,3 \%$ ), w miejscowym $26,5 \%$ $(n=50)$, a w regionalnym $4,7 \%(n=9)$ badanych. Zdecydowana większość badanych przyjęta została do szpitala w trybie planowanym $(n=158 ; 83,6 \%)$. Pozostali respondenci przyjęci byli w trybie pilnym ( $n=31 ; 16,4 \%)$. Ponad połowa ankietowanych osób ( $n=103 ; 54,5 \%$ ) określiła swoje doznania bólowe występujące po operacji jako miejscowe. Mniejsza grupa badanych ( $n=62 ; 32,8 \%$ ) wskazała na ból rozlany. Na rozległość doznań bólowych jako ograniczone wskazało 4,2\% ( $n=8)$ badanych, a uogólnione 8,5\% ( $n=16)$. Najliczniejsza grupa badanych osób określiła swój charakter bólu jako kłujący (Tabela 1).

Tabela 1. Charakter bólu w opinii ankietowanych Table 1. The nature of the pain of the respondents

\begin{tabular}{|c|c|c|c|c|c|c|}
\hline \multirow{2}{*}{$\begin{array}{l}\text { Charakter bólu/ } \\
\text { The nature of pain }\end{array}$} & \multicolumn{6}{|c|}{$\mathrm{N}=189$} \\
\hline & $K=110$ & $\%$ & $M=79$ & $\%$ & $\begin{array}{l}\text { Razem/ } \\
\text { Together }\end{array}$ & $\%$ \\
\hline $\begin{array}{l}\text { Tępy/ } \\
\text { A dull }\end{array}$ & 28 & 14,81 & 7 & 3,70 & 35 & 18,52 \\
\hline $\begin{array}{l}\text { Ostry/ } \\
\text { Sharp }\end{array}$ & 57 & 30,16 & 51 & 26,98 & 108 & 57,14 \\
\hline $\begin{array}{l}\text { Kłujący/ } \\
\text { Stabbing pain }\end{array}$ & 68 & 35,98 & 66 & 34,92 & 134 & 70,90 \\
\hline $\begin{array}{l}\text { Gniotący/ } \\
\text { Crushing }\end{array}$ & 26 & 13,76 & 2 & 1,06 & 28 & 14,81 \\
\hline $\begin{array}{l}\text { Pulsujący/ } \\
\text { Throbbing pain }\end{array}$ & 15 & 7,94 & 19 & 10,05 & 34 & 17,99 \\
\hline $\begin{array}{l}\text { Promieniujący/ } \\
\text { Radiating }\end{array}$ & 15 & 7,94 & 8 & 4,23 & 23 & 12,17 \\
\hline $\begin{array}{l}\text { Inny (jaki?) piekący/ } \\
\text { Other (what?) Burning pain }\end{array}$ & 9 & 4,76 & 0 & 0,00 & 9 & 4,76 \\
\hline
\end{tabular}

* Procenty nie sumuja się do 100, ponieważ respondenci mieli możliwość wyboru więcej niż jednej odpowiedzi.

Źródło: opracowanie własne

Source: author's own analysis
W opinii większości respondentów ich ból w okresie pooperacyjnym miał charakter nawracający ( $n=146$; 77,25) (Tabela 2).

Tabela 2. Zmienność bólu w opinii pacjentów Table 2. The variability of the pain of the patients

\begin{tabular}{lccccccc}
\hline $\begin{array}{l}\text { Zmienność doznania bólu/ } \\
\text { Variability of pain sensation }\end{array}$ & $\mathrm{K}=110$ & $\%$ & $\mathrm{M}=79$ & $\%$ & $\begin{array}{c}\text { Razem/ } \\
\text { Together }\end{array}$ & $\%$ \\
\hline $\begin{array}{l}\text { Ciągły/ } \\
\text { Constant pain }\end{array}$ & 11 & 5,82 & 6 & 3,17 & 17 & 8,99 \\
$\begin{array}{l}\text { Przerywany/ } \\
\text { Intermittent pain }\end{array}$ & 6 & 3,17 & 7 & 3,71 & 13 & 6,88 \\
$\begin{array}{l}\text { Napadowy/ } \\
\text { Paroxysmal pain }\end{array}$ & 1 & 0,53 & 0 & 0 & 1 & 0,53 \\
$\begin{array}{l}\text { Nawracający/ } \\
\text { Recurrent pain }\end{array}$ & 86 & 45,51 & 60 & 31,75 & 146 & 77,25 \\
$\begin{array}{l}\text { O zmiennym natężeniu/ } \\
\text { Pain of varying intensity }\end{array}$ & 6 & 3,17 & 6 & 3,17 & 12 & 6,35 \\
$\begin{array}{l}\text { Razem/ } \\
\text { Total }\end{array}$ & 110 & 58,20 & 79 & 41,80 & 189 & 100 \\
\hline
\end{tabular}

Źródło: opracowanie własne

Source: author's own analysis

W opinii ponad połowy ( $\mathrm{n}=109 ; 57,67 \%$ ) badanych pacjentów ból najsilniejszy był w pierwszej dobie po zabiegu. Jedna czwarta pacjentów ( $n=49 ; 25,93 \%$ ) za najbardziej dokuczliwy uznała ból w drugiej dobie po zabiegu operacyjnym. Dla $15,87 \%(n=30)$ badanych najsilniejszy był ból bezpośrednio po zabiegu w zerowej dobie, natomiast jedna osoba $(0,53 \%)$ wskazała trzecią dobę jako dzień najsilniejszego bólu po wykonanej operacji. W większości przypadków ( $n=161 ; 85,2 \%$ ) bólowi pooperacyjnemu towarzyszyły inne objawy. Najczęściej były to nudności ( $n=108) 57,5 \%$ i wymioty $(\mathrm{n}=73 ; 38,6 \%)$. Skurcze występowały u $11,1 \%$ ( $\mathrm{n}=$ 21) badanych, zaburzenia oddychania u $9 \%(n=17)$, a omdlenia u 3,7\% $(n=7)$ badanych. Jako „inne” badani najczęściej wymieniali tępe bóle w klatce piersiowej, osłabienie, bóle głowy, karku i szyi, problemy z oddychaniem, bóle pachwiny ( $n=68 ; 36 \%$ ). Pytanie o objawy towarzyszące było pytaniem wielokrotnego wyboru. U większości badanych ( $n=149 ; 78,8 \%)$ ból powodował znaczne ograniczenie aktywności ruchowej. U 43\% ( $n=$ 81) badanych ból miał duży wpływ na odpoczynek senny, u ponad połowy ( $n=104 ; 55 \%$ ) nieznacznie zaburzał sen. Jedynie u $2 \%(n=4)$ ankietowanych ból nie powodował zaburzeń snu. U prawie wszystkich badanych ból pooperacyjny spowodował znaczne ( $n=38 ; 20,1 \%)$ lub nieznaczne obniżenie nastroju ( $n=146 ; 77,25 \%$ ). W sytuacji bólu pooperacyjnego badani w większości reagowali najczęściej przyśpieszeniem tętna ( $\mathrm{n}=157$; $83,07 \%$ ), reakcją nerwową ( $\mathrm{n}=117 ; 61,9 \%)$, wzmoże- 
niem napięcia mięśniowego ( $\mathrm{n}=113 ; 59,79 \%$ ) i/lub podwyższeniem ciśnienia tętniczego krwi ( $n=103 ; 54,5 \%)$ (pytanie wielokrotnego wyboru). Większość badanych osób odczuwała intensyfikację bólu podczas ruchu ( $\mathrm{n}=$ 136; $72 \%$ i zmiany pozycji ( $n=117 ; 62 \%)$. W mniejszym stopniu natężenie bólu wzmacniał u badanych kaszel ( $n=47 ; 25 \%)$ i głębszy oddech ( $n=34 ; 18 \%)$. Pytanie o sytuacje nasilające ból pooperacyjny było pytaniem wielokrotnego wyboru. Podawane środki przeciwbólowe w opinii badanych przyniosły ulgę w umiarkowanym stopniu u ponad połowy ankietowanych ( $\mathrm{n}=112$; $59,3 \%$ ), niewielkie obniżenie bólu nastąpiło u 34,9\% badanych $(n=66)$. Znaczną ulgę po podaniu środków przeciwbólowych odczuło zaledwie $5 \%$ badanych $(\mathrm{n}=$ 10; 5,3\%). Brak zniesienia odczucia bólu wskazała tylko jedna badana $(n=1 ; 0,5 \%)$. Większość ankietowanych ( $n=136 ; 72 \%$ ) w okresie okołooperacyjnym prosiła o dodatkową dawkę leków minimalizujących ból. Niestety większość badanych, poza lekami przeciwbólowymi, nie zna innych sposobów łagodzenia bólu ( $n=133$; $70,4 \%$ ). Większość badanych została poinformowana o stosowanym w szpitalu leczeniu przeciwbólowym ( $n=150 ; 79,4 \%$ ), pozostali badani $(n=39 ; 20,6 \%$ ) nie wiedzieli, czy byli informowani o postępowaniu przeciwbólowym. Większość badanych o leczeniu przeciwbólowym została poinformowana przez lekarza anestezjologa ( $n=170 ; 89,95 \%)$ oraz pielęgniarkę ( $n=134 ; 70,9 \%)$. O postępowaniu przeciwbólowym informował badanych również lekarz danego oddziału ( $\mathrm{n}=88 ; 46,56 \%$ ). Pytanie o osobę informującą o postępowaniu p/bólowym było pytaniem wielokrotnego wyboru. W opinii $77,25 \%$ ( $n=146$ ) badanych po zabiegu operacyjnym było u nich wykonane badanie natężenia bólu. Brak dokonywania pomiaru bólu wskazało 8,46\% $(n=16)$ respondentów, natomiast 14,29\% ( $n=27)$ badanych nie pamiętało, czy miało wykonany pomiar natężenia bólu. Ponad połowa ( $n=107 ; 56,61 \%$ ) badanej populacji chorych wskazała, że pomiarów bólu dokonywano dwukrotnie w ciągu doby. Trzy razy dziennie pomiaru dokonano w przypadku 15,34\% ( $n=29$ ) respondentów. Raz dziennie badanie natężenia poziomu bólu wykonano w 14,29\% ( $n=27)$ badanych pacjentów. U pięciu osób (2,65\%) pomiaru intensywności dokonano wielokrotnie, natomiast $11,11 \%(n=21)$ badanych nie pamięta ilości pomiarów natężenia bólu lub deklaruje, że nie wykonywano u nich takiego pomiaru. Od personelu pielęgniarskiego większość pacjentów po zabiegu operacyjnym oczekuje sumiennego i delikatnego wykonywania zabiegów oraz pomocy w minimalizowaniu bólu. Pomoc w samoopiece i samopielęgnacji to czynnik wsparcia ważny dla ponad 70\% ankietowanych (Tabela 3).

Tabela 3. Oczekiwane wsparcie ze strony pielęgniarek Table 3. Expected support from nurses

\begin{tabular}{|c|c|c|c|c|c|c|}
\hline \multirow{2}{*}{$\begin{array}{l}\text { Oczekiwane wsparcie ze } \\
\text { strony pielęgniarek/ } \\
\text { Expected support from } \\
\text { nurses }\end{array}$} & \multicolumn{6}{|c|}{$\mathrm{N}=189$} \\
\hline & $K=110$ & $\%$ & $M=79$ & $\%$ & $\begin{array}{l}\text { Razem/ } \\
\text { Together }\end{array}$ & $\%$ \\
\hline $\begin{array}{l}\text { W zabiegach pielegnacyjnych/ } \\
\text { In the care treatments }\end{array}$ & 22 & 11,64 & 14 & 7,41 & 36 & 19,05 \\
\hline $\begin{array}{l}\text { W sumiennym i delikatnym } \\
\text { wykonywaniu zabiegów/ } \\
\text { In conscientious and gentle } \\
\text { treatment }\end{array}$ & 106 & 56,08 & 78 & 41,27 & 184 & 97,35 \\
\hline $\begin{array}{l}\text { W minimalizowaniu bólu/ } \\
\text { In minimizing pain }\end{array}$ & 107 & 56,61 & 77 & 40,74 & 184 & 97,35 \\
\hline $\begin{array}{l}\text { W ułożeniu/ } \\
\text { In the patient's position }\end{array}$ & 14 & 7,41 & 11 & 5,82 & 25 & 13,23 \\
\hline $\begin{array}{l}\text { W pionizacji i uruchamianiu/ } \\
\text { In the upright position and } \\
\text { starting the patient }\end{array}$ & 32 & 16,93 & 37 & 19,58 & 69 & 36,51 \\
\hline $\begin{array}{l}\text { W przyswajaniu wiedzy/ } \\
\text { In acquiring knowledge }\end{array}$ & 5 & 2,65 & 2 & 1,06 & 7 & 3,70 \\
\hline $\begin{array}{l}\text { W samoopiece i samopie- } \\
\text { lęgnacji } \\
\text { związanej ze schorzeniem/ } \\
\text { In self-care and self-care } \\
\text { associated } \\
\text { with the disease }\end{array}$ & 86 & 45,50 & 47 & 24,87 & 133 & 70,37 \\
\hline $\begin{array}{l}\text { W kontakcie z rodziną/ } \\
\text { In contact with family }\end{array}$ & 1 & 0,53 & 0 & 0,00 & 1 & 0,53 \\
\hline
\end{tabular}

* Procenty nie sumują się do 100, ponieważ respondenci mieli możliwość podania więcej niż jednej odpowiedzi

Źródło: opracowanie własne

Source: author's own analysis

Analizując natężenie bólu u pacjentów, wzięto pod uwagę takie czynniki, jak: wiek, płeć, wykształcenie, zatrudnienie badanych oraz formy wsparcia udzielanego przez personel pielęgniarski podczas pobytu pacjentów na oddziale. Analiza statystyczna wykazała istotną zależność pomiędzy wiekiem ankietowanych a ich poziomem odczucia natężenia bólu. Z tabeli 4 wynika, że osoby najstarsze odczuwały wyższe nasilenie bólu w porównaniu z osobami w młodszych grupach wiekowych, zwłaszcza w grupie wiekowej od 20 do 40 lat (Tabela 4). 
Tabela 4. Natężenie bólu z uwzględnieniem wieku pacjentów Table 4. The intensity of pain, including the age of the patients

\begin{tabular}{|c|c|c|c|c|c|c|c|c|}
\hline $\begin{array}{l}\text { Natężenie bólu } \\
\text { a wiek/The intensity } \\
\text { of pain and age }\end{array}$ & $\mathrm{N}$ & $\begin{array}{l}\text { Średnia/ } \\
\text { Average }\end{array}$ & $\begin{array}{c}\text { Odchylenie } \\
\text { standardowe/ } \\
\text { Standard } \\
\text { deviation }\end{array}$ & $\begin{array}{l}\text { Błąd standardowy/ } \\
\text { Standard error }\end{array}$ & $\begin{array}{l}\text { Minimum/ } \\
\text { Minimum }\end{array}$ & $\begin{array}{l}\text { Maksimum/ } \\
\text { Maximum }\end{array}$ & $\mathrm{F}$ & $\begin{array}{l}\text { Istotnośćl } \\
\text { Statistical } \\
\text { significance }\end{array}$ \\
\hline $20-30$ & 14 & 5,7143 & 1,68379 & 0,45001 & 2,00 & 7,00 & \multirow{8}{*}{8,781} & \multirow{8}{*}{0,000} \\
\hline $31-40$ & 43 & 5,1860 & 1,20031 & 0,18305 & 3,00 & 7,00 & & \\
\hline $41-50$ & 54 & 6,2407 & 0,79941 & 0,10879 & 4,00 & 7,00 & & \\
\hline $51-60$ & 30 & 5,9333 & 0,82768 & 0,15111 & 5,00 & 7,00 & & \\
\hline $61-70$ & 26 & 5,8462 & 0,61269 & 0,12016 & 5,00 & 7,00 & & \\
\hline $71-80$ & 18 & 6,0000 & 0,00000 & 0,00000 & 6,00 & 6,00 & & \\
\hline $81-90$ & 4 & 8,0000 & 0,00000 & 0,00000 & 8,00 & 8,00 & & \\
\hline Razem/Total & 189 & 5,8730 & 1,04920 & 0,07632 & 2,00 & 8,00 & & \\
\hline
\end{tabular}

Źródło: opracowanie własne

Source: author's own analysis

Tabela 5. Natężenie bólu a wykształcenie pacjentów

Table 5. The intensity of pain and education of the patients

\begin{tabular}{|c|c|c|c|c|c|c|c|c|}
\hline $\begin{array}{c}\text { Natężenie bólu } \\
\text { a wykształcenie/ } \\
\text { The intensity of } \\
\text { pain and education }\end{array}$ & $\mathrm{N}$ & $\begin{array}{l}\text { Średnia/ } \\
\text { Average }\end{array}$ & $\begin{array}{c}\text { Odchylenie } \\
\text { standardowe/ } \\
\text { Standard deviation }\end{array}$ & $\begin{array}{c}\text { Błąd } \\
\text { standardowy/ } \\
\text { Standard error }\end{array}$ & $\begin{array}{l}\text { Minimum/ } \\
\text { Minimum }\end{array}$ & $\begin{array}{l}\text { Maksimum/ } \\
\text { Maximum }\end{array}$ & $\mathrm{F}$ & $\begin{array}{l}\text { Istotność/ } \\
\text { Statistical } \\
\text { significance }\end{array}$ \\
\hline $\begin{array}{l}\text { Podstawowe/ } \\
\text { Basic }\end{array}$ & 2 & 7,0000 & 0,00000 & 0,00000 & 7,00 & 7,00 & \multirow{9}{*}{4,147} & \multirow{9}{*}{0,000} \\
\hline $\begin{array}{l}\text { Zasadnicze } \\
\text { zawodowe/ } \\
\text { Vocational }\end{array}$ & 40 & 6,4750 & 1,03744 & 0,16403 & 5,00 & 8,00 & & \\
\hline $\begin{array}{l}\text { Średnie zawo- } \\
\text { dowe/Secondary } \\
\text { vocational }\end{array}$ & 84 & 5,6905 & 1,25128 & 0,13653 & 2,00 & 7,00 & & \\
\hline $\begin{array}{l}\text { Średnie ogólne/ } \\
\text { General secondary }\end{array}$ & 2 & 6,0000 & 0,00000 & 0,00000 & 6,00 & 6,00 & & \\
\hline $\begin{array}{l}\text { Wyższe zawodowe/ } \\
\text { Higher vocational }\end{array}$ & 9 & 5,4444 & 0,52705 & 0,17568 & 5,00 & 6,00 & & \\
\hline $\begin{array}{l}\text { Licencjat/ } \\
\text { Bachelor's degree }\end{array}$ & 30 & 6,0000 & 0,00000 & 0,00000 & 6,00 & 6,00 & & \\
\hline Inżynier/Engineer & 2 & 6,0000 & 0,00000 & 0,00000 & 6,00 & 6,00 & & \\
\hline $\begin{array}{l}\text { Wyższe } \\
\text { magisterskie/ } \\
\text { Master's degree }\end{array}$ & 20 & 5,3000 & 0,47016 & 0,10513 & 5,00 & 6,00 & & \\
\hline Razem/Total & 189 & 5,8730 & 1,04920 & 0,07632 & 2,00 & 8,00 & & \\
\hline
\end{tabular}

Źródło: opracowanie własne

Source: author's own analysis

Analiza statystyczna wykazała również istotną zależność pomiędzy wykształceniem ankietowanych a ich poziomem odczucia natężenia bólu. Pacjenci z wykształceniem podstawowym i zawodowym wykazali wyższy stopień natężenia bólu pooperacyjnego (Tabela 5).
Nie wykazano natomiast zależności statystycznie istotnej pomiędzy płcią badanych (Tabela 6), zatrudnieniem (Tabela 7) oraz różnymi formami wsparcia udzielanego przez personel pielęgniarski (Tabela 8) a stopniem natężenia bólu. 
Tabela 6. Natężenie bólu a płeć pacjentów

Table 6. The intensity of pain and the gender of patients

\begin{tabular}{|c|c|c|c|c|c|c|}
\hline \multicolumn{2}{|c|}{$\begin{array}{l}\text { Natężenie bólu a płećl } \\
\text { The intensity of pain and the gender }\end{array}$} & $\mathrm{N}$ & $\begin{array}{l}\text { Średnia/ } \\
\text { Average }\end{array}$ & $\begin{array}{l}\text { Odchylenie standardowe/ } \\
\text { Standard deviation }\end{array}$ & $t$ & $\mathrm{p}$ \\
\hline \multirow{2}{*}{$\begin{array}{l}\text { Proszę określić natężenie Pani/ } \\
\text { Pana odczucia bólu/ } \\
\text { Please, specify the intensity } \\
\text { of your pain sensation }\end{array}$} & Kobieta/Female & 110 & 6,0545 & 1,03902 & \multirow{2}{*}{0,879} & \multirow{2}{*}{0,350} \\
\hline & Mężczyzna/Male & 79 & 5,6203 & 1,01658 & & \\
\hline
\end{tabular}

Źródło: opracowanie własne

Source: author's own analysis

Tabela 7. Natężenie bólu a zatrudnienie pacjentów

Table 7. The intensity of pain and employment of patients

\begin{tabular}{|c|c|c|c|c|c|c|c|}
\hline $\begin{array}{l}\text { Natężenie bólu a zatrudnienie/ } \\
\text { The intensity of pain and employment }\end{array}$ & $\mathrm{N}$ & $\begin{array}{l}\text { Średnia/ } \\
\text { Average }\end{array}$ & $\begin{array}{c}\text { Odchylenie } \\
\text { standardowe/ } \\
\text { Standard } \\
\text { deviation }\end{array}$ & $\begin{array}{l}\text { Minimum/ } \\
\text { Minimum }\end{array}$ & $\begin{array}{l}\text { Maksimum/ } \\
\text { Maximum }\end{array}$ & $\mathrm{F}$ & $\begin{array}{r}\text { Istotność/ } \\
\text { Statistical } \\
\text { significance }\end{array}$ \\
\hline $\begin{array}{l}\text { Zatrudniony na czas określony/ } \\
\text { Employed for a definite period }\end{array}$ & 25 & 7,1000 & 0,25400 & 7,00 & 7,00 & \multirow{10}{*}{2,217} & \multirow{10}{*}{0,145} \\
\hline $\begin{array}{l}\text { Zatrudniony na czas nieokreślony/ } \\
\text { Employed for an indefinite period }\end{array}$ & 109 & 6,2500 & 1,03744 & 5,00 & 8,00 & & \\
\hline $\begin{array}{l}\text { Zatrudniony na umowę zlecenie/ } \\
\text { Employed on contract work }\end{array}$ & 1 & 5,1105 & 0,25800 & 2,00 & 7,00 & & \\
\hline $\begin{array}{l}\text { Kontrakt/ } \\
\text { Contract }\end{array}$ & 2 & 6,2100 & 1,40000 & 6,00 & 6,00 & & \\
\hline $\begin{array}{l}\text { Niepracujący/ } \\
\text { Not employed }\end{array}$ & 3 & 5,0444 & 0,52705 & 5,00 & 6,00 & & \\
\hline $\begin{array}{l}\text { Gospodyni domowa/ } \\
\text { Housewife }\end{array}$ & 3 & 6,6600 & 0,33400 & 6,00 & 6,00 & & \\
\hline $\begin{array}{l}\text { Emeryt/ka/ } \\
\text { Pensioner }\end{array}$ & 31 & 5,0300 & 0,14000 & 6,00 & 6,00 & & \\
\hline $\begin{array}{l}\text { Rencista/ka/ } \\
\text { Pensioner }\end{array}$ & 14 & 4,9000 & 0,47016 & 5,00 & 6,00 & & \\
\hline $\begin{array}{l}\text { Bezrobotny/ } \\
\text { Unemployed }\end{array}$ & 1 & 5,1000 & 0,24000 & & & & \\
\hline $\begin{array}{l}\text { Razem/ } \\
\text { Total }\end{array}$ & 189 & 5,8730 & 1,04920 & 2,00 & 8,00 & & \\
\hline
\end{tabular}

Źródło: opracowanie własne

Source: author's own analysis

Tabela 8. Natężenie bólu pacjentów a wsparcie personelu pieleggniarskiego Table 8. The intensity of pain of the patients and the support of nursing staff

\begin{tabular}{|c|c|c|c|c|c|}
\hline $\begin{array}{l}\text { Natężenie bólu a wsparcie personelu/ } \\
\text { The intensity of pain and the support of nursing staff }\end{array}$ & $\mathrm{N}$ & $\begin{array}{l}\text { Średnia/ } \\
\text { Average }\end{array}$ & $\begin{array}{l}\text { Odchylenie stan- } \\
\text { dardowe/ } \\
\text { Standard deviation }\end{array}$ & $\mathrm{F}$ & $\mathrm{p}$ \\
\hline W zabiegach pieleggnacyjnych/In the care treatments & 36 & 5,8800 & 0,35400 & \multirow{9}{*}{1,488} & \multirow{9}{*}{0,589} \\
\hline $\begin{array}{l}\text { W sumiennym i delikatnym wykonywaniu zabiegów/In conscientious and gentle } \\
\text { treatment }\end{array}$ & 184 & 6,4900 & 1,23744 & & \\
\hline W minimalizowaniu bólu/In minimizing pain & 184 & 6,1105 & 0,14800 & & \\
\hline W ułożeniu/In the patient's position & 25 & 6,8500 & 1,25000 & & \\
\hline W pionizacji i uruchamianiu/In the upright position and starting the patient & 69 & 5,1244 & 0,52705 & & \\
\hline W przyswajaniu wiedzy/ln acquiring knowledge & 7 & 5,0200 & 0,33400 & & \\
\hline $\begin{array}{l}\text { W samoopiece i samopielęgnacji związanej ze schorzeniem/In self-care and self- } \\
\text { care associated with the disease }\end{array}$ & 133 & 4,9900 & 0,14000 & & \\
\hline W kontakcie z rodziną/In contact with family & 1 & 5,2800 & 0,47016 & & \\
\hline Razem/Total & 639 & 5,8730 & 1,04920 & & \\
\hline
\end{tabular}

Źródło: opracowanie własne

Source: author's own analysis 


\section{Dyskusja}

Ból jest nieodłącznym, wielowymiarowym zjawiskiem, przenikającym każdą sferę naszego życia i organizmu. Ból związany z chorobą, hospitalizacją i leczeniem operacyjnym to doznanie specyficzne i bardzo trudne dla pacjenta. Schorzenie leczone operacyjnie wiąże się z zagrożeniem życia, bólem i cierpieniem. Czas okołooperacyjny wypełniony jest obawami, lękami o przyszłość i sprawność chorego. Udzielenie pomocy i wsparcia w tym okresie nabiera szczególnego znaczenia.

Z badań własnych wynika, iż subiektywne doznanie bólu u pacjentów po zabiegu operacyjnym mieściło się na średnim poziomie. Wielu autorów badających zjawisko bólu pooperacyjnego również potwierdza takie wyniki $[9,10]$.

Zjawisko bólu pooperacyjnego uwarunkowane jest wieloma składowymi, między innymi: rodzajem schorzenia, wykonanym zabiegiem operacyjnym oraz znieczuleniem. Różnorodność schorzeń, tryb przyjęcia do szpitala, rodzaj wykonanych zabiegów i dokonanego znieczulenia zróżnicowała populację badanych osób i ich umiejscowienie bólu. W opinii badanych pacjentów ból po zabiegu operacyjnym najsilniej odczuwany był w dwóch pierwszych dobach. Takie odczucia po zabiegach operacyjnych potwierdzają również inni autorzy [11, 12]. W badaniu własnym uwzględniono czynniki społeczne, takie jak: wiek, płeć, wykształcenie, zatrudnienie oraz miejsce zamieszkania chorych w ocenie bólu po zabiegu operacyjnym. Dziki Ł. i wsp. [13] wskazują, iż im osoby starsze, tym bardziej jest obniżony próg bólowy i niższe natężenie bólu, co nie miało odzwierciedlenia w badaniu własnym. W badaniu własnym zaistniała zależność pomiędzy wiekiem a stopniem natężenia bólu. Wraz z wiekiem u badanych osób stwierdzono większe natężenie bólu. Wynik ten może sugerować nakładanie się kilku schorzeń współistniejących podczas leczenia zabiegowego.

W badaniu własnym ujawniono nieco większe natężenie bólu u kobiet w porównaniu z mężczyznami, choć nie zaobserwowano istotnej statystycznie zależności. Zależność pomiędzy płcią a natężeniem bólu potwierdza literatura przedmiotu [13].

W badaniu własnym wykazano statystycznie istotną zależność pomiędzy wykształceniem a poziomem odczucia natężenia bólu. Pacjenci z wykształceniem podstawowym i zawodowym wykazali wyższe natężenie bólu pooperacyjnego. Zależność między wykształceniem a natężeniem bólu przewlekłego wykazały również badania przeprowadzone przez Rzepkę I. oraz Wordliczka J. [14]. W badaniach własnych nie zaobser- wowano zależności statystycznie istotnych w przypadku innych czynników społeczno-demograficznych.

W badaniach Baczewskiej B. i wsp. na temat opinii dotyczących charakteru bólu respondenci określali ból jako dokuczliwe, przykre, kłujące i świdrujące zjawisko [10]. W badaniach własnych ankietowani określali ból jako kłujący i ostry oraz nawracający. Wielu autorów literatury przedmiotu wskazuje na miejscowe doznanie bólu po zabiegu operacyjnym w miejscu rany lub wyjścia drenów $[12,15]$. W badaniu własnym chorzy również ocenili swój ból jako doznanie miejscowe.

Uzyskane wyniki badań własnych ujawniły występowanie objawów towarzyszących bólowi, takich jak wymioty i nudności. Reakcje respondentów na ból objawiały się przyśpieszonym tętnem, reakcją nerwową, wzmożonym napięciem mięśni i podwyższonym ciśnieniem tętniczym krwi oraz ograniczeniem aktywności ruchowej. Wśród ankietowanych ból zaburzał ilość i jakość snu, wpływając również na obniżenie nastroju. Podobne wyniki dotyczące jakości snu uzyskała Boryga M. i Włoszczak-Szubzda A. [16] oraz Jakubów P. i wsp. [12].

Kolejnym aspektem badania bólu pooperacyjnego było jego najsilniejsze odczucie. W przeprowadzonym badaniu własnym chorzy zgłaszali najsilniejsze odczucia bólowe w pierwszej dobie po zabiegu, co potwierdzają również badania innych autorów [12, 15, 16].

W badaniach Prochowicz D. i wsp. [15] przedstawiono dużą skuteczność i zadowolenie badanych z zastosowanego leczenia przeciwbólowego. Uzyskane wyniki badań własnych ujawniły umiarkowaną ulgę w leczeniu minimalizującym ból oraz niewystarczające obniżenie natężenia bólu i konieczność przyjmowania dodatkowych dawek leków przeciwbólowych przez chorych. Wskazują one na potrzebę dokładnego monitorowania stopnia natężenia bólu oraz konieczność zweryfikowania postępowania przeciwbólowego.

Badania Jurczak A. i wsp. [17] wskazują na potrzebę wsparcia informacyjnego pacjentów w czasie okołooperacyjnym. Inni autorzy literatury przedmiotu również wyrażali konieczność udzielenia pomocy w minimalizowaniu bólu, w sumiennym i delikatnym wykonywaniu zabiegów [18].

Podsumowując przeprowadzone badanie, należy zauważyć, iż ból towarzyszący pacjentom po zabiegu operacyjnym jest odczuciem fizjologicznym. Oznacza to, że konieczna jest stała obserwacja i wdrażanie standardów dotyczących minimalizowania bólu. W dalszym ciągu pacjenci zgłaszają większą potrzebę komunikacji i pozyskania informacji oraz wsparcia w sytuacji pooperacyjnej. 


\section{Wnioski}

1. Średnie natężenie bólu pooperacyjnego $\mathrm{w}$ badanej populacji nie przekraczało $6 \mathrm{w}$ dziesięciostopniowej skali oceny poziomu natężenia bólu.

2. U osób starszych oraz osób z wykształceniem podstawowym i zawodowym stwierdzano większe natężenie bólu pooperacyjnego.

3. Istnieje ciągła potrzeba edukacji oraz wsparcia pacjentów po zabiegu operacyjnym.

\section{Piśmiennictwo}

1. Hilgier M. Ból przewlekły - problem medyczny i społeczny. Przewodnik Lekarza, 2002; 5, 1/2: 6-11.

2. Heszen I, Sęk H. Psychologia zdrowia. Warszawa: PWN; 2008.

3. Wordliczek J, Dobrogowski J. Leczenie bólu. Warszawa: PZWL; 2011.

4. Kocot-Kępska M, Dobrogowski J. Rodzaje bólu. W: Andres J, Dobrogowski J. (red). Neurologia, znieczulenie regionalne i terapia bólu. J. Kraków: Ośrodek Regionalny CEEA; 2011.

5. Weinert M. (red) Kubler A. Anestezjologia. Wrocław: Urban \&Partner; 2008.

6. Rupniewska-Ładyko A. Terapia bólu pooperacyjnego. W: Krajewska-Kułak E, Rolka H, Jankowiak B. (red.) Standardy anestezjologicznej opieki pielęgniarskiej. Warszawa: PZWL; 2014.

7. Suchorzewski M. Ból i jego leczenie. W: Wolowicka L, Dyk D (red). Anestezjologia i Intensywna Opieka. Klinika i Pielęgniarstwo. Warszawa: PZWL; 2008.

8. Wordliczek J. Ból pooperacyjny. W: Wordliczek J, Dobrogowski J (Red.). Ból ostry. Kraków: Wydawnictwo Uniwersytetu Jagiellońskiego; 2002.

9. Rybicka A. Czy nadzór pielęgniarski ma wpływ na ryzyko miejscowych powikłań krwotocznych, odczuwanie bólu i komfort chorego po chirurgicznym udrożnieniu tętnic szyjnych? Pielęgniarstwo Chirurgiczne i Angiologiczne 2017; 11 (2): 68-72.

10. Baczewska B, Kropornicka B, Drozd C, Olszak C. Ocena bólu, lęku i depresji u pacjentów hospitalizowanych z powodu choroby nowotworowej W: Majchrzak-Kłokocka E, Szelga R. (Red). Wybrane problemy organizacji i zarządzania w pielęgniarstwie. Pielęgniarstwo bez granic. Łódź: Wydawnictwo Społecznej Akademii Nauk; 2013.

11. Grochans E, Hyrcza V, Kuczyńska M, Szkup-Jabłońska M, Jurczak A, Rotter I, Zaremba-Pechmann L, Karakiewicz B.
Subiektywna ocena bólu pooperacyjnego u pacjentów po wybranych zabiegach chirurgicznych. Pielęgniarstwo Chirurgiczne i Angiologiczne 2011; 2: 82-87.

12. Jakubów P, Sewastianowicz A, Kalinowska W, Dubowski M, Juszczyk G, Hirnle T. Ocena zachowań bólowych pacjentów po operacjach kardiochirurgicznych. Anestezjologia i Ratownictwo 2017; 11: 138-151.

13. Dziki Ł, Glińska J, Borowiak E, Krzemińska M, Dziki A. Czynniki determinujące kontrolę bólu u chorych po zabiegach kardiochirurgicznych Pielęgniarstwo Chirurgiczne i Angiologiczne 2017; 11(1): 26-31.

14. Repka I, Wordliczek J. Wpływ czynników demograficznospołecznych na natężenie bólu, jakość życia oraz jej poszczególne składowe wśród chorych z bólem przewlekłym. Problemy Pielęgniarstwa 2013; 21(3): 348-359.

15. Prochowicz D, Krajewska-Kułak E, Trochimowicz L. Skala bólu pooperacyjnego w percepcji pacjentów Oddziału Urologii Onkologicznej i Ogólnej. Pielęgniarstwo Chirurgiczne i Angiologiczne 2014; 4: 170-179.

16. Boryga M, Włoszczak-Szubzda A. Szpital bez bólu. Realizacja programu w opiniach pacjentów oddziałów zabiegowych Aspekty Zdrowia i Choroby 2016; 1, 2: 7-22.

17. Jurczak A, Kiryk A, B, Kotwas A, Pawlik J, Celewicz A, Szkup M, Grochans E. Ocena jakości opieki pielęgnacyjnej w zakresie bólu pooperacyjnego. Fam Med Primary Care Rev 2015; 17,2: 107-110.

18. Kapała W, Skrobisz J. Oczekiwania pacjentów hospitalizowanych w oddziale chirurgii trybem planowym względem zespołu lekarskiego, pielęgniarskiego i warunków lokalowych. Now Lek 2006; 75, 4: 351-358.

Artykuł przyjęty do redakcji: 11.10.2019.

Artykuł przyjęty do publikacji: 31.03.2020.

Źródło finansowania: Praca nie jest finansowana z żadnego źródła. Konflikt interesów: Autorzy deklarują brak konfliktu interesów.

\section{Adres do korespondencji:}

Anna Gawęda

ul. Królowej Jadwigi 18

41-704 Ruda Śląska

tel. 322407110

e-mail: agaweda@wsnsrs.edu.pl

Wydział Opieki Zdrowotnej, Wyższa Szkoła Nauk Stosowanych w Rudzie Śląskiej 